\title{
EVALUATION OF BEEF CHARACTERISTICS OF AYRSHIRE BULLS BASED ON PROGENY GROUPS
}

\author{
HiLкKa RUOHомÄкI \\ Agricultural Research Centre, Department of Animal Breeding, Tikkurila \\ Mikкo VARo \\ University of Helsinki, Department of Animal Breeding, Viikki
}

Received February 10, 1969

For several years running the Uusimaa and Kymi AI Center in Westerkulla has been testing the beef characteristics of Ayrshire bulls by means of male progeny groups. A test ending in the spring of 1967 comprised progeny groups from nine Ayrshire bulls, i.e. 72 bull calves. The sires were AI bulls, some of these still lacking a progeny test result.

The average number of calves per group was 8 . They were incorporated into the test at the age of 3-14 days, but by timing the slaughter according to age the differences in age were levelled down to 1.9 days. The mean age at slaughter was 182.7 days.

F e e d ing was uniform for all, i.e. 55-60 litres of whole milk, 950 litres of skim milk, $340-360 \mathrm{~kg}$ of concentrates fed ad lib., 80 - $90 \mathrm{~kg}$ of molasses, $65-75 \mathrm{~kg}$ of hay (KosKuLL 1968).

E va l u a t i o n of $\mathrm{c}$ a $\mathrm{r}$ c a s s e s was made by eye-appraisal in the usual manner (KARLsson 1953). The best, or E-class, consisted of 15 carcasses; 35 were qualified for the second best $(\mathrm{I}+)$ and 21 for the next one $(\mathrm{I})$; only one carcass was graded $\mathrm{I}-$. The results of the evaluation showed that the between-sire variance was statistically significant only as far as the grading of the round and the shoulder was concerned.

The cutting was performed at the Etelä-Suomi Co-operative Slaughterhouse, where the valuable expertise and skilled workmanship, which made this part of the study possible, was available. The carcasses were sawed in half along the spine, and $\mathrm{t} h \mathrm{e} \mathrm{r} \mathrm{ig} \mathrm{h} \mathrm{t}$ $\mathrm{h}$ a l $\mathrm{f}$ of the carcass was cut. The greatest difference within the group in average weight of the left and right half was $940 \mathrm{~g}$, the difference between averages for the whole material being only $200 \mathrm{~g}$.

The carcass half was cut into fore and hind parts between the 7th and 8th ribs counting from the front. The fore part comprises the fore back, the neck, the brisket, the shoulder, 
and the fore shin, as well as the so called wedge, separated from the curving of the brisket The back part consists of the round with shank, the back, the flank, and the side (Fig. 1). In each part the meat, bone, fat and tendon tissue were separated. The meat was sorted

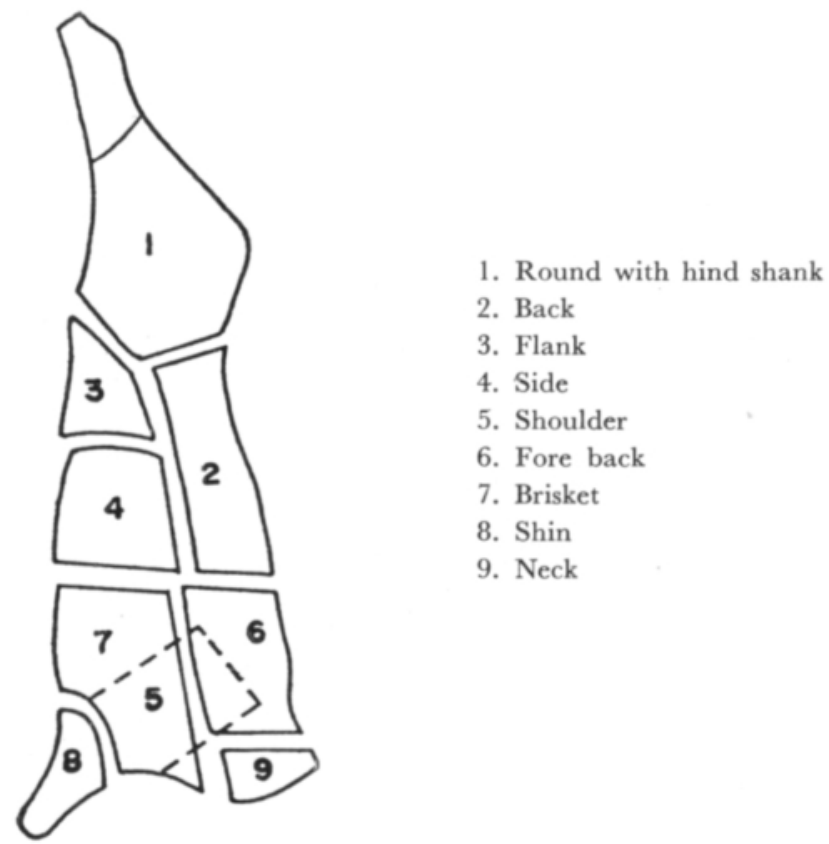

Fig. 1. Cutting scheme of a neat carcass.

into grades I, II, and III. Grade III includes some fat and membranes, adding perhaps about one percent to the total meat content. This, however, was not taken into account in the calculations; thus grade III meat was regarded as full meat tissue.

\section{Results}

When the different parts of the carcass and the results from the cutting of these were computed as percentages, more than 200 comparative characteristics became available for each animal. The results were analysed by the analysis of variance RoBERTSON (1959) in order to evaluate the share of the between-sire variation of the total variation and to estimate the heritability of some characteristics. In the following only the most important qualities will be discussed. Table 1 .

The between-sire differences in initial weight and dressing out percentage were not statistically significant. The dressing out percentages are small compared to similar values in foreign studies, which is due to the fact that they were based on the weight of the cold carcass, and that carcass weight does not include inner organs or fats.

The results of cutting show the between-sire differences in kilogrammes to be statistically significant, which is due to the differences in weight of the carcasses. The relative values do not, however, differ significantly. Table 2. 


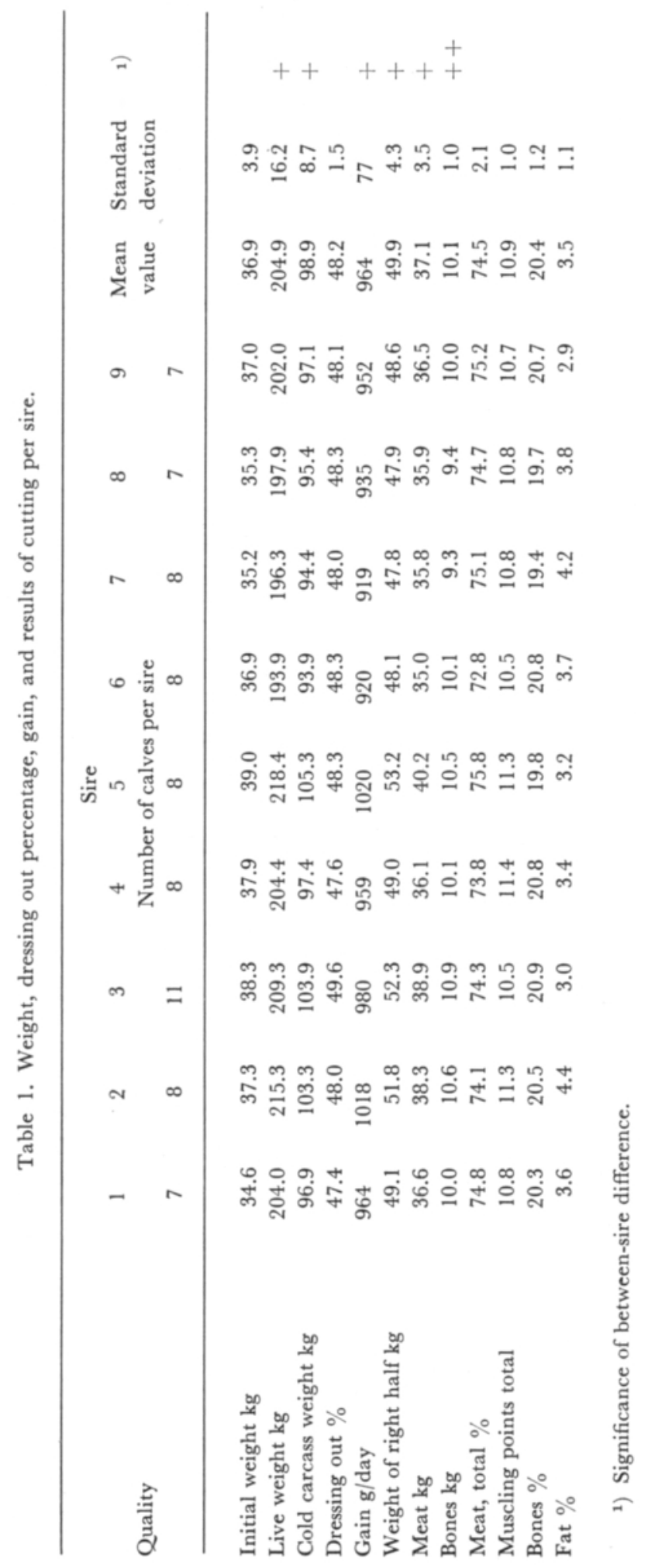




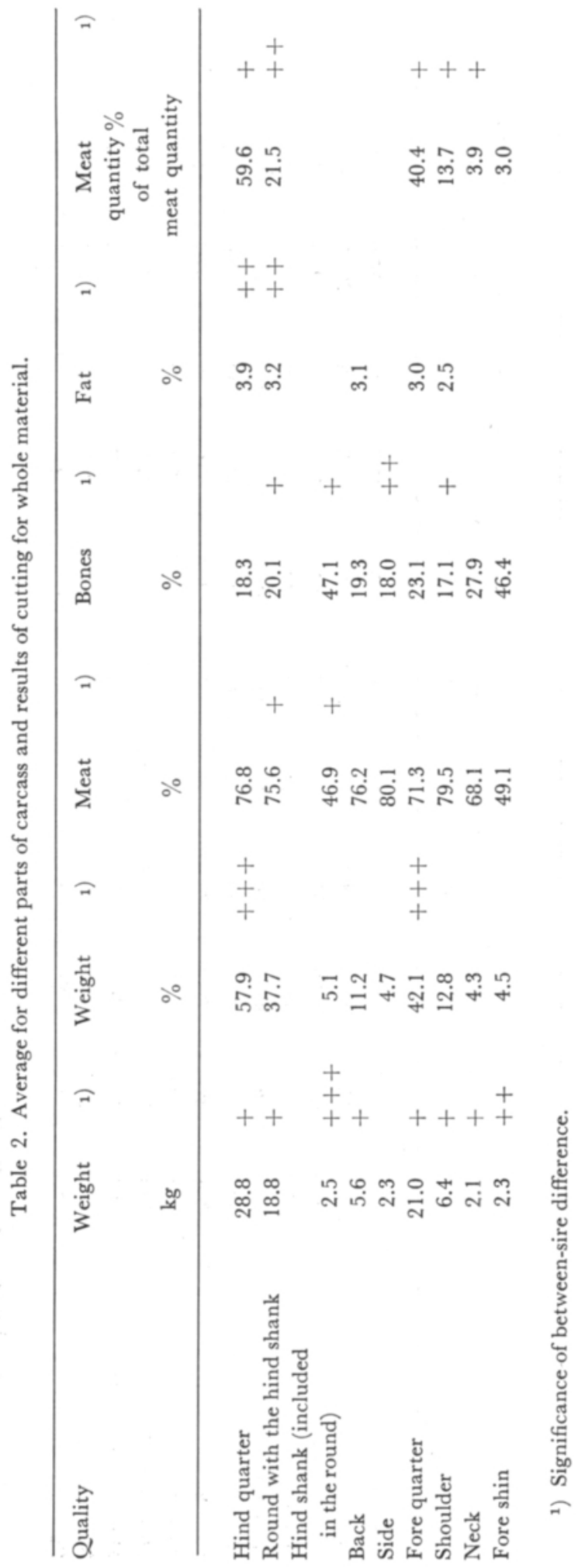


The between-sire difference for weights of hind and fore parts and their share of the carcass weight are statistically significant. No statistically significant between-sire difference was, however, found for the relative weights of any smaller part of the carcass. In meat and bone percentage the difference is significant only for the round and hind shank parts, the latter being already icluded in the round. In bone percentage there is a significant between-sire variation for the side and shoulder. But as there is a statistically significant between-sire diffrence between the meat content of different parts in percent of total meat content of the carcass, this is a sign of the different body conformation of the animals.

In connection with the cutting, a cross section of the mus c u l u s $\mathrm{lon}$ g i s s i m us d o r s i (MLD) between the 7th and 8th ribs was also drawn. The area averaged $24.2 \mathrm{~cm}^{2}$, the standard deviation being $2.7 \mathrm{~cm}^{2}$. No statistical diffrences were found between sires. Many foreign studies have paid great attention to the interdependence between the area of MLD and various qualities of the carcass. Thus SKJERvold (1958) has found statistically very dependable correlations between the area of MLD and carcass weight, dressing out percentage and meat content of hind part of the carcass. Cole et al. (1960) obtained a correlation of +0.43 between area and amount of meat in the carcass, Goll et al. (1961) a correlation of +0.52 between area and carcass weight, and GRAVERT (1962) a correlation +0.37 , Good et al. (1961) +0.28 to +0.36 between area and live weight, and Haring et al. $(1958)+0.46$ between area an d meatiness percentage. The cross sections in these foreign studies were made at different points and on different breeds of animals.

In an earlier study with animals of different breeds and ages the present authors (RUономёкI and VARo 1967) found that the MLD area of Ayrshires differed from that of others and suggested that contemporary Ayrshire-animals might show a connection between the MLD area and meatiness percentage. No statiscally significant connection was, however, found even in the present material either with the meatiness percentage or with the weight of carcass or with the amount of meat in carcass.

For length of MLD on the other hand, there was a significant between-sire difference. Group 2 had the longest MLD and group 4 the shortest. The difference was $3 \mathrm{~cm}$. Number 4 had the best slaughter evaluation grades, although its weight was only average. Apparently the form of the carcass influences evaluation so that shorter animals are given higher grades because they look rounder than long ones. HARING in the study mentioned above draws the same conclusions, as does BRÄNNÄNG (1967). In this study no association between the length of MLD and meatiness grade was, however, found.

The grades for meatiness gave no clue to the meat percentage of the carcass or to the carcass weight or to the actual amount of meat, although earlier studies (RUономӓкі 1967 and Ruономӓкі \& VARo 1967) have shown grades for meatiness to follow the two latter characteristics.

It may be noted that $\mathrm{the} s \mathrm{~h}$ are of between-sire variance of the to t a l variance for weight in kilogrammes of various parts of the carcass is rather high, but in percentages only the shares of the hind and fore parts are statistically highly significant. (Table 3).

The amounts of meat from different parts of the carcass have in many instances quite a high numerical value, but only the variance for the meatines percentage of the round 
Table 3. Between-sire variance $\%$ of the total variance.

Quality

1)

Live weight $\mathrm{kg}$

Cold carcass weight $\mathrm{kg}$

Dressing out \%

Gain $\mathrm{g} /$ day

Area of MLD $\mathrm{cm}^{2}$

Length of MLD cm

Points, total

First class meat in the carcass

Meat in the carcass

Bones " " "

HIND QUARTER

Meat

Bones

Fat

Meat quantity $\%$ of total meat quantity

FORE QUARTER

Meat

Bones

Meat quantity $\%$ of total meat quantity

ROUND WITH HIND SHANK

Meat

Bones

Fat

Meat quantity $\%$ of total meat quantity

BACK

Meat

SIDE

Bones

SHOULDER

Meat

Bones

Meat quantity $\%$ of total meat quantity

NECK

Meat

Meat quantity $\%$ of total meat quantity

HIND SHANK

Meat

Bones

FORE SHIN

Bones

1) Significance of between-sire difference.

$\begin{array}{rr}15.98 & + \\ 15.35 & + \\ 7.66 & - \\ 12.58 & + \\ 1.04 & - \\ 18.07 & + \\ 1.84 & -\end{array}$

\begin{tabular}{|c|c|c|c|}
\hline $\mathrm{kg}$ & 1) & $\%$ & 1) \\
\hline 19.24 & ++ & 15.84 & + \\
\hline 13.10 & + & 5.23 & - \\
\hline 20.08 & ++ & 10.04 & - \\
\hline 15.10 & + & 31.57 & +++ \\
\hline 13.11 & + & 9.42 & - \\
\hline 18.79 & ++ & 9.80 & - \\
\hline \multirow[t]{2}{*}{17.48} & + & 18.98 & ++ \\
\hline & & 16.62 & + \\
\hline 13.85 & + & 31.59 & +++ \\
\hline 13.64 & + & 3.14 & - \\
\hline \multirow[t]{2}{*}{11.99} & + & 1.42 & - \\
\hline & & 16.63 & + \\
\hline 17.24 & + & 4.12 & - \\
\hline 14.72 & + & 13.37 & + \\
\hline 26.04 & ++ & 15.81 & + \\
\hline \multirow[t]{2}{*}{18.43} & ++ & 18.56 & ++ \\
\hline & & 20.27 & ++ \\
\hline 12.00 & + & 10.97 & - \\
\hline 17.27 & + & - & - \\
\hline 1.63 & 一 & 9.62 & - \\
\hline 17.38 & + & 24.40 & ++ \\
\hline 11.94 & + & 9.85 & - \\
\hline 13.91 & + & - & - \\
\hline \multirow[t]{2}{*}{10.01} & - & 12.65 & + \\
\hline & & 14.20 & + \\
\hline 17.44 & + & 6.90 & - \\
\hline \multirow[t]{2}{*}{22.35} & ++ & 2.95 & - \\
\hline & & 15.80 & + \\
\hline 33.41 & +++ & 7.82 & - \\
\hline 16.34 & + & 16.36 & + \\
\hline 30.34 & $++t$ & 14.60 & + \\
\hline 19.25 & ++ & 9.48 & - \\
\hline 19.48 & ++ & 7.97 & - \\
\hline
\end{tabular}




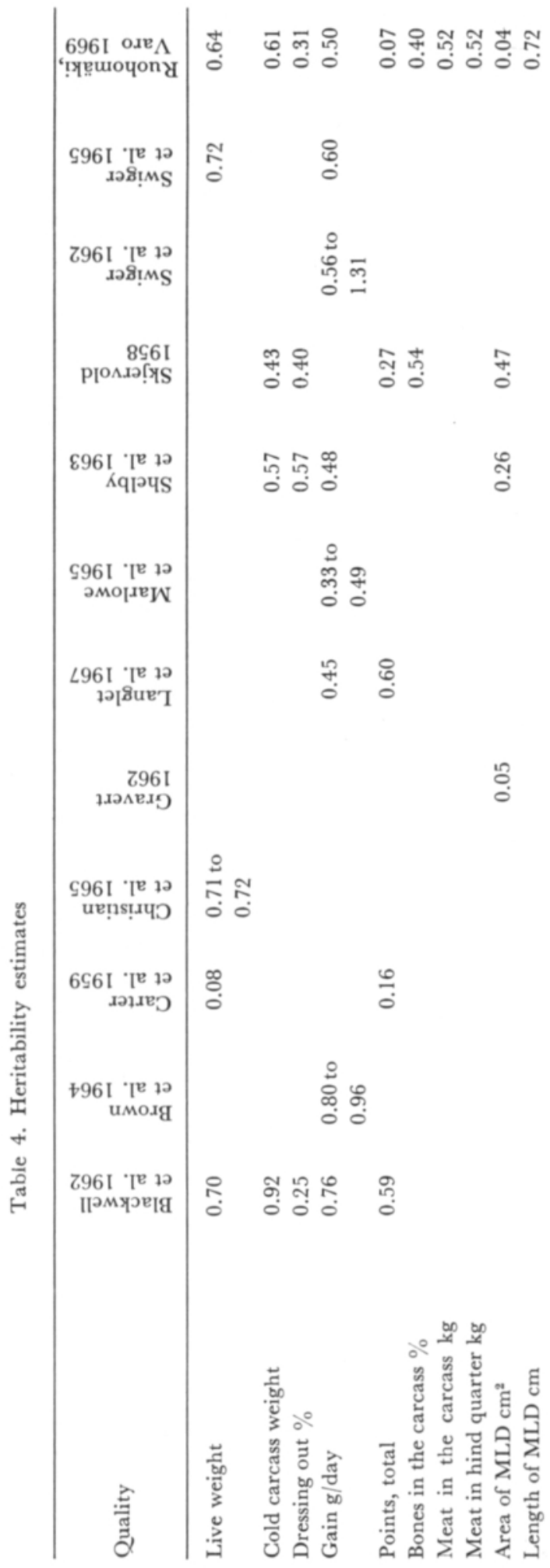


and hind shank belonging to the round are statistically significant. On the other hand, when calculating the amounts of meat of different parts of the carcass in proportions to the total meat content of the carcass, the between-sire variance values were high. The amounts in kilogrammes and proportions in percent of grade I meat are also rather high and statistically significant.

The amounts of bone in different parts of the carcass are in percentages and in kilogrammes more clearly heritable than the amounts of meat.

\section{Heritability estimates}

The heritability calculations of the most important characteristics were based on the between-sire variance. The calculations were made according to LUSH (1936) using the factor 0.25 . Table 4 .

The heritability of live weight was estimated at 0.64 for the present material. This corresponds very closely to similar values in foreign studies based on different materials, but great disagreement can also be noted.

The 0.61 heritability of carcass weight agrees well with estimates in foreign studies.

Very many estimates of the heritability of the gaining ability have been made abroad. The material of the present study gave a heritability of 0.50 for daily gain.

Many estimates of heritability have also been made for cutting results, but their comparative value is hampered by the cutting practices differing in many countries.

The quality of the carcass is another factor influencing the economic result. A heritability of 0.50 was calculated for grade results of rounds and shoulders of the present material. No other values had any statistical significance.

\section{Conclusions}

Progeny groups with an average of 8 bull calves from nine Ayrshire bulls were raised on uniform feeding where concentrates were fed ad lib., to an age of 6 months. The carcasses were evaluated, and their right half was cut. In order to estimate the between-sire variance and the heritability values, analyses of variance were performed.

The between-sire variances were statistically significant for live weights and carcass weights and thus also for the weights of carcass half. The between-sire variance for results in kilograms was generally statistically significant, but for proportions in per cent the values were significant only in a few instances. The differences between sires were statistically highly significant for the relative proportions of fore and hind parts, which presumably is due to the sires being of different body conformation.

The between-sire variance with regard to the amount of meat in kilogram is statistically significant for almost all parts of the carcass, but - except for the round - the differences with regard to meatiness percentage are slight.

The amounts of meat obtained from different parts of the carcass, expressed as proportions of the total amount of meat, varies statistically significantly in most cases, which also points to the differences in body conformation of the animals. 
The area of the musculus longissimus dorsi was neither correlated with the weight of the carcass nor with the meatiness percentage.

There was no difference between the sires with regard to the carcass grading except the round and shoulder. The grades for meatiness gave no clue to the meat percentage of the carcass or to the carcass weight or to the actual amount of meat, although earlier studies have shown grades of meatiness to follow the two latter characteristics.

It may be pointed out that the present study is a preliminary one and will be completed with further trials.

\section{REFERENCES}

Blackwell, R. L., Knox, J. H., Shelby, C. E. \& Clark, R. T. 1962. Genetic analysis of economic characteristics of young Hereford cattle. J. An. Sci., 21: 101-107.

Brown, C. J. \& GacUlA, M. 1964. Estimates of heritability of beef cattle performance traits by regression of offspring on sire. IBID, 23: 321-324.

BRÄNNÄNG, E. 1967. Kan klassificeringen av nötkött förenklas och förbättras? Sv. Husdjursskötsel 1967/1: 5-9.

Garter, R. C. \& Kincaid, C. M. 1959. Estimation of genetic and phenotypic parameters in beef cattle. II Heritability estimates from parent-offspring and half-sib resemblances. J. An. Sci., 18: 323-330.

Christian, L. L., Hauser, E. R. \& Chapman, A. B. 1965. Heritability estimates in beef cattle based on identical and fraternal twin data. IBID, 24: 643-651.

Cole, J. W., Orme, L. E. \& Kincaid, C. M. 1960. Relationship of loin eye area, separable lean of various beef cuts and carcass measurements to total carcass lean in beef. IBID, 19: 89-99.

Coll, D. E., HAzEL, L. N. \& KLINE, E. A. 1961. Relationship between some beef carcass measurements and yields of wholesale cuts. IBID, 20: 264-267.

Good, D. L., DAhl, G. M., WeArden, S. \& Weseli, D. J. 1961. Relationship among live and carcass characteristics of selected slaughter steers. IBID, 20: 698-707.

Gravert, H. O. 1962. Untersuchungen über die Erblichkeit von Fleischeigenschaften beim Rind. 1. Mitteilung. Z. für Tierz. und Z-biol., 78: 43-74.

Haring, F., Gruhn, R. \& TÄger, E. 1958. Nachkommenprüfung auf Mastleistung und Schlachtwert beim Rind. II. Z-kunde, 30: 148-155.

KarLsson, G. 1953. Boken om kött. S. 89-112, Bengt Forslunds Förlag, Malmö.

von Koskull, B. 1968. Sonnivasikoiden kasvatuskokeet. Karjatalous 44: 116-119.

Langlet, J. F., Gravert, H. O. \& Rosenhahn, E. 1967. Untersuchungen über die Erblichkeit der Fleischleistung bei Schwarzbunten Rindern. Z. für Tierz. und Z-biol., 83: 358-370.

Lush, J. L. 1936. Genetic aspects of the Danish system of progeny testing swine. Iowa Agric. Exp. Sta. Res. Bull. 204.

Marlowe, T. J. \& Vogt, D. W. 1965. Heritabilities, phenotypic correlations and genetic correlations involving preweaning gain and weaning grade of beef calves. J. An. Sci., 24: 502-506.

Robertson, A. 1959. Populationsgenetik und quantitative Vererbung. Handbuch der Tierzüchtung, 2: 77-104. Hamburg und Berlin.

RUономӓкі, H. 1967. Charolaisristeytyskokeiden tuloksia. Ref. Results of Charolais crossbreeding trials in Finland. Ann. Agric. Fenn., 6: 115-126.

-»- \& VARo, M. 1967. Effect of crossing with Charolais on the beef yield of slaughter animals based on results gained in the cutting of carcasses. Acta Agr. Fenn. 109, 1: 154-163.

Shelby, C. E., Harvey, W. R., Clark, R. T., Quesenberry, J. R. \& Woodward, R. R. 1963. Estimates of phenotypic and genetic parameters in ten years of miles city R.O.P. steer data. J. An. Sci., 22: $346-353$.

SKJERvold H. 1958. Registrering av köttproduksjonsegenskapene hos Sto fe. Summary: Regist ation of meat production characteristics in cattle. Norges Landbrukshøgskole, Meld. 123: 1-143. 
Swiger, L. A., Косн, R. M., Gregory, K. E. \& Arthaud, V. H. 1962. Selecting beef cattle for economical gain. J. An. Sci., 21: 588-592.

-》- Gregory, K. E., Sumption, L. J., Breidenstein, B. C. \& Arthaud, V. H. 1965. Selection indexes for efficiency of beef production. IBID, 24: $418-424$.

\title{
SELOSTUS
}

\section{AYRSHIRESONNIEN LIHANANTIOMINAISUUKSIEN ARVOSTELUSTA JÄLKELÄISRYHMIEN PERUSTEELLA}

\author{
HiLKкA RUOHOMÄкI \\ Maatalouden tutkimuskeskus, Kotieläinjalostuslaitos, Tikkurila \\ Mikko VARo \\ Helsingin yliopisto, Kotieläinten jalostustieteen laitos, Viikki
}

Yhdeksän ayrshiresonnin poikaryhmät, joissa oli keskimäärin 8 vasikkaa, kasvatettiin vapaalla väkirehuruokinnalla puolen vuoden ikäisiksi. Ruhot arvosteltiin ja niiden oikea puolikas paloiteltiin. Tulokset käsiteltiin varianssianalyysilla isien välisen muuntelun ja perinnöllisyyden osuuden arvioimiseksi.

Elopainojen ja teuraspainojen isien väliset erot olivat tilastollisesti merkitseviä. Kilomääräisissä tuloksissa oli isien välinen muuntelu yleensä tilastollisesti merkitsevää. Takapään suhteellisen osuuden erittäin merkitsevien isien välisten erojen otaksutaan osoittavan isien olevan rakenteellisesti erilaisia ja myös periyttävän rakenneominaisuutensa pojilleen. Rakenne-eroihin viittaa myös se, että eri ruhon osista saatujen lihamäärien suhteellisten osuuksien erot ovat useissa ominaisuuksissa tilastollisesti merkitseviä isien välillä.

Joidenkin ominaisuuksien kuten takapään osuuden ja takapotkan ja sen luumäärän isien välinen muuntelu oli varsin suuri.

Pitkän selkälihaksen alalla ei ollut mitään yhteyttä enempää ruhon painoon kuin lihamäärään tai lihakkuusprosenttiinkaan.

Teurasarvostelupisteissä oli isien välillä merkitsevät erot vain sisäpaistien ja lapojen pistemäärissä. Lihakkuuspisteet eivät antaneet kuvaa ruhojen lihakkuudesta eikä lihamääristä.

Saadut tulokset ovat alustavia ja niitä täydennetään ja tarkistetaan myöhemmistä kokeista saatavilla tuloksilla. 